\title{
Ravitsejad Siberi eesti kogukondades
}

\author{
Anu Korb \\ Eesti Kirjandusmuuseumi Eesti Rahvaluule Arhiivi vanemteadur \\ anu.korb@folklore.ee
}

\begin{abstract}
Teesid: Artikli analüüsimaterjaliks on erinevatest Siberi eesti kogukondadest talletatud rahvameditsiini aines, mis on kogutud Eesti Rahvaluule Arhiivi välitöödel ajavahemikus 1991-2013. Kuna arusaamine tervisest on tihedalt seotud kogukonnaga, sotsiaalse elu ja keskkonnaga, analüüsin kogukonnaliikmete hinnangutele tuginedes ravioskuste omandamist, teadmiste edasiandmise võimalusi ja ravitseja staatust erinevates Siberi eesti kogukondades. Toon esile ka Siberi eesti kogukondade piirkondlikke eripärasid.

Hoolimata riikliku meditsiiniabi jõudmisest Siberi eestlaste küladesse pärast Teist maailmasõda oli rahvameditsiiniga seonduv külastatud kogukondades meie vaadeldaval perioodil osa kogukonna igapäevaelust ja seetõttu vägagi nähtaval. Vanemates Siberi eesti kogukondades jagati oma teadmisi kõigile soovijaile, raviloitse samastati kõigile kättesaadava jumalasõnaga. Väljarännanutest alguse saanud kogukondades suhtuti ravitarkuste edasiandmisse märksa ettevaatlikumalt.

Siberi eesti kogukondade märgatav vananemine ja vähenemine 21. sajandi esimestel kümnenditel seab kahtluse alla traditsiooni jätkusuutlikkuse.
\end{abstract}

Märksõnad: kogukond, rahvameditsiin, ravitsejad, Siberi eestlased

\section{Sissejuhatus}

Artikli analüüsimaterjaliks on Siberi eesti kogukondades sündinud-kasvanud eestlastelt Eesti Rahvaluule Arhiivi välitöödel ajavahemikus 1991-2013 talletatud rahvameditsiini aines: käsikirjalised ülestähendused ning heli- ja videosalvestused.

Välitööde käigus töötasime Omski, Novosibirski, Kemerovo ja Tomski oblasti ning Krasnojarski krai eesti kogukondades. Külastatud piirkonnad erinevad suuresti nii asustusloo kui ka loodusolude poolest. Varasemad asundused, kus elas samuti eestlasi, said alguse Vene tsaarivalitsuse perioodil väljasaadetutest ja sundasunikest ning moodustati algselt luteriusuliste sega-asundustena, nt Lääne-Siberis Rõžkovo (asutatud umbes 1800), Ida-Siberis Ülem-Suetuk (1850) (Must 2012: 305-402).

Väljarändamine Siberisse sai tsaaririigi koloniseerimispoliitika suunamisel alguse 19. sajandi viimasel kümnendil pärast Lääne-Siberi raudtee valmimist ja hoogustus 20. sajandi alguskümnenditel (Kulu 1997: 91). Välja rännati sageli hulgakesi ühest piirkonnast. Nii säilisid võõrsil pikka aega kodukandi keel 
ja kombed. August Nigol märgib oma 1918. aastal välja antud raamatus, et "terve Siber on eestlasi täis" (Nigol 1918: 38) ja annab järgnevatel lehekülgedel ülevaate Eesti asundustest Siberis 20. sajandi alguskümnendeil.

Veel 21. sajandi algul võis Siberis eristada lõuna- ja põhjaeestikeelseid eesti kogukondi (1980. aastate kohta vt Viikberg \& Vaba 1984: 145-149) ning tuvastada piirkondlikke eripärasid. 20. sajandi viimasel kümnendil leidsime Siberis eest umbes 40 eesti kogukonda, elanike arv olenevalt asukohast 25-300. Eestlased elasid sel ajal enamasti paljurahvuselistes külades, üksikud enamvähem eestikeelsena säilinud külad asusid raskesti ligipääsetavates paikades suurtest teedest eemal (Korb 2005: 22-23).

Välitöödel tegime tähelepanekuid ka Siberi eestlaste argielu kohta, kuid eeskätt püüdsime talletada võimalikult mitmekesist traditsioonilist pärimust. Rahvameditsiiniga seonduv oli enamikus külastatud kogukondadest meie vaadeldaval perioodil osa kogukonna igapäevaelust ja seetõttu vägagi nähtaval.

Artiklis jälgin eesti kogukonna liikmete suhtumist endi seast võrsunud rahvaarstidesse ja teistest rahvustest ravitsejatesse. Kuna arusaamine tervisest on tihedalt seotud kogukonnaga, sotsiaalse elu ja keskkonnaga, jälgin kogukonnaliikmete hinnangutele tuginedes, kuidas Siberi eestlaste kogukonnas ravioskusi omandatakse ja edasi antakse, kuidas suhtutakse ravitsejasse kogukonnas, mis tingib ravivõimete vähenemise või kadumise. Püüan välja tuua ka Siberi eesti kogukondade piirkondlikke eripärasid.

\section{Taust ja olud}

Asunduste algusaegadel Siberis polnud elanikel võimalustki õppinud arstide poole pöörduda. Seega oli sel perioodil ravitsejate esilekerkimine ja ravioskuste omandamine tingitud praktilisest vajadusest. Sarnane oli 20. sajandi esimestel kümnenditel olukord ka Eestis jm Euroopas - maaelanikele ja vaesemale linnarahvale jäi arstiabi suuresti kättesaamatuks (vt nt Kõivupuu 2013: 71).

Siberi asunike usuelu eest hakkas hoolitsema Moskva luterlik konsistoorium. Esmalt tegutsesid külades rändpastorid, hiljem määrati kohapeale kösterkooliõpetaja. Siberis usu- ja hariduselu juhtimise kõrval jäi vaimuliku pädevusse ka hoolekanne haigete ja vaeste eest (Granö 1999: 129), mille katkestas oktoobripöörde-järgne enamlaste võimuletulek ja usuelu keelustamine. Riikliku meditsiini võidukäik - antibiootikumide kasutuselevõtt, ravi kättesaadavus ja pidev selgitustöö vähendasid mõneti rahvaarstide osatähtsust. Pärast Teist maailmasõda rakendatud riiklikud meetmed tõid Siberi külade elanikele arstiabi nn koju kätte (nt küladesse jõudsid kooliharidusega meditsiinitöötajad, avati velskripunktid, kohapeal anti sünnitusabi). 


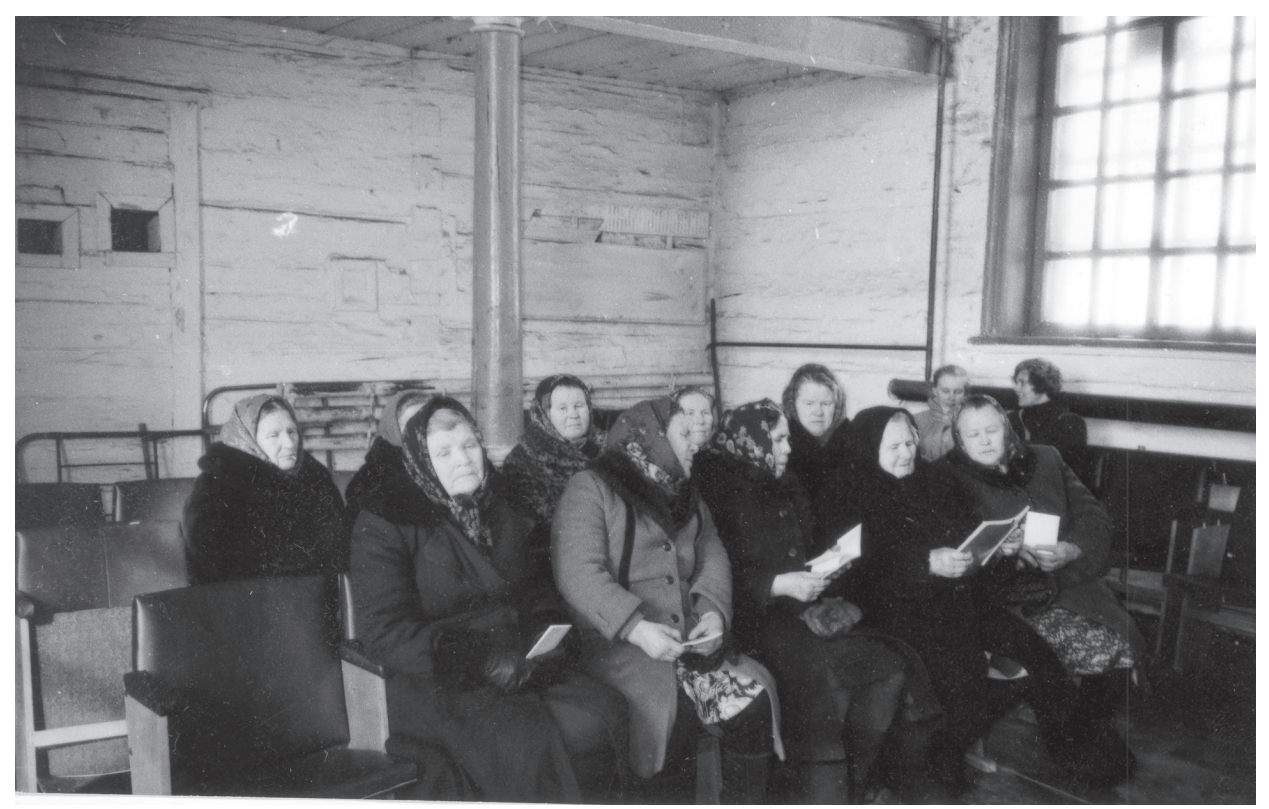

Foto 1. Ülem-Suetuki rahvas kirikus. Kadri Peebo foto 1992. ERA, Foto 15020.

Oma mõju avaldas ka rahvaarstide sattumine nõukogude võimuorganite põlu alla, kuna ravitsejate tegevus oli Nõukogude Liidus keelustatud ja karistatav kuni 1980. aastate alguseni, mil Leonid I. Brežnev andis rahvaarstide tegutsemiseks vabad käed (Kõivupuu 2000: 172). Eesti rahvaarste ja meediume uurinud Mare Kõiva tõdeb, et rahvameditsiini ja -arste soosivad ajad saabusid siis, kui rahvapärase arstimise järjepidevus oli jõudnud enamikus Eestimaa paigus katkeda (Kõiva 1995: 183).

Õigeusklike naabrite mõjuväljas kasvanud Siberi eestlaste sõnamaagia tundmine oli märksa laiemalt levinud kui Kodu-Eestis. Soodustavaks teguriks oli ka pikaaegne elamine traditsioonilises külakogukonnas. Mõneti aitas just Siberi eestlastest ravitsejate rohkus - peaaegu igaüks oskas mõne häda puhul abi anda - kaasa sellele, et nende tegevus ei torganud väljapoolsetele eriliselt silma. Samas avaldas paratamatult pärimuse edasiandmisele mõju teadmine ravitegevusele järgneda võivast karistusest (Korb 2006: 92).

Nõukogude Liidu lagunemine, sealhulgas Eesti iseseisvuse taastamine, tõi 1990. aastail kaasa keerulised majandusolud: lagunesid ühismajandid, valitses terav tööpuudus. Siberi eesti külade elanikele pakkus sestpeale äraelamisvõimalust isiklik loomakasvatus ja põllupidamine. Ülikiire inflatsiooni tingimustes, samuti Vene Föderatsiooni ja Eesti Vabariigi vahel viisarežiimi sisseseadmise 
tõttu vähenes Siberi eestlaste suhtlus oma Eestimaa sugulastega. Eestimaalt tulnud kultuuriuurija oli eriti 1990. aastail Siberi eesti kogukondades väga oodatud just harvaks jäänud kontaktide tõttu emamaaga. 21. sajandi alguseks olid majandusolud mõneti paranenud ja kahe riigi elanike suhtlus taastunud. Samas olid vananeva elanikkonnaga kogukonnad kiiresti hääbumas.

Rahvaluulekogujatel ${ }^{1}$ puudus kogumistöö algul ülevaade kõigist Siberi küladest, kus eestlasi kompaktselt elab. Meie esimene retk 1991. aasta suvel Krasnojarski krai eestlaste juurde kujunes tõeliseks elamuseks. Tol reisil väisatud Ülem-Suetuki külas elas siis umbes 300 inimest, kes kõik oskasid eesti keelt. Ülem-Bulanka külas elas veel paarkümmend peret, eesti keelt räägiti neist pooltes. Et kaugel Siberi külas saab päriselt suhelda eesti keeles, oli juba iseenesest üllatav, põnev oli talletada ka elavat ja rikkalikku pärimust (Korb 2017: 9-10). Kuna Eesti välitöötraditsioon oli olnud pikka aega minevikku suunatud, külades oli palju heade pärimusteadmistega eesti keelt kõnelevaid inimesi, keskendusime esmalt vanemate eestlaste küsitlemisele.

\section{Soorollid ja naiste osa kogukonna traditsioonis}

Siberi eesti külades on traditsioonikandjad, sealhulgas rahvameditsiini tundjad, enamasti vanemad naised. Siinjuures toon esile mõned selle olukorra tekkepõhjused.

Ühes rahvusliku liikumisega hakati Eestis 19. sajandi teisel poolel pöörama tähelepanu ka naiste rollile ja õigustele ühiskonnas, kuid oluliste muutusteni (nt naiste ligipääs gümnaasiumi- ja kõrgkooliharidusele, valimisõigus) jõuti alles 20. sajandi esimestel kümnenditel. Siberisse väljarändamise perioodil olid soorollid kindlalt paigas: mees oli perekonnapea, naine tegutses peamiselt kodusfääris. Suuremad muutused Siberi eesti kogukondades said alguse pärast nõukogude võimu kehtestamist, eriti alates 1930. aastaist, mil elanikud pidid sundkorras taludest ühismajanditesse koonduma. Järgnenud ulatuslikud repressioonid puudutasid eeskätt mehi. Meeste vangistamise ja küladesse alles jäänud meeste Teise maailmasõtta mobiliseerimise järel jäi nii kolhoosi- kui ka pereelu peamiselt naiste kanda. Nõukogude sooideoloogia lähtus ideest vabastada naised patriarhaalsetest peresidemetest ja anda neile võimalus end töö kaudu teostada. Naiste tööpanuse olulisust nähti maa industraliseerimise kontekstis, laste eest pidi hoolitsema riik (Ashwin 2000: 10). Paljudes Siberi külades organiseeriti lastesõimed ja -aiad, aga lapsed olid sageli kodus ka omapäi, naised olid sunnitud tegema pikki päevi ühismajandis. Soorollid privaatsfääris ei muutunud oluliselt ka pärast sõda - naiste õlule jäi suuresti kodune majapidamine ja järeltulijate eest hoolitsemine, hoolimata sellest, et naiselt eeldati 
tööpanust ka väljapool kodu. Mehed on olnud läbi aegade liikuvamad, tegutsenud naistest enam kodust väljapool, ka muukeelses keskkonnas. Just naised on pidanud oluliseks hoida sidet mineviku ja pärimusega. Naiste osatähtsuse kasvule aitas kaasa ka Siberi külade demograafiline olukord - vanemaid naisi on meestest tunduvalt rohkem.

\section{Ravitsejad külades ja riiklik meditsiin}

Kuigi riiklik meditsiiniabi oli jõudnud Siberi eestlaste küladesse umbes pool sajandit varem, oli rahvapäraste ravimisviiside ja -võtete kasutamine 1990. aastail vanemates Siberi eesti kogukondades, aga ka paljudes hilisemates, väljarännanutest alguse saanud eesti kogukondades pärimusrühma ühisteadmine: ravitsejad kogukonnas eriliselt esile ei tõusnud, sest oskused ja ravisõnad arvati olevat igaühele kättesaadavad ja õpitavad.

Meil on külas niuksi pallu. [---] Vedoma Mari oskab, Miku Anni oskab, Petju Helena oskab, tema Poljaka, Ignatovitša Mari oskab, Pauliina oskab, a kes siin viel oskab, see Pahmernõi Vilma oskab siin otsas: ruosi, ehmatamisest, silmamisest, pistuksest. No oskavad, pallu oskavad inimesed. Daže Naaritsa Sanjagi oskab. (ERA, CD 459 (5) < Omski obl, Rõžkovo k - naine, snd 1913 (1999))

Foto 2. Ravitseja Mari Vedom. Rõžkovo k. Astrid Tuisu foto 1999. ERA, VF 3098.

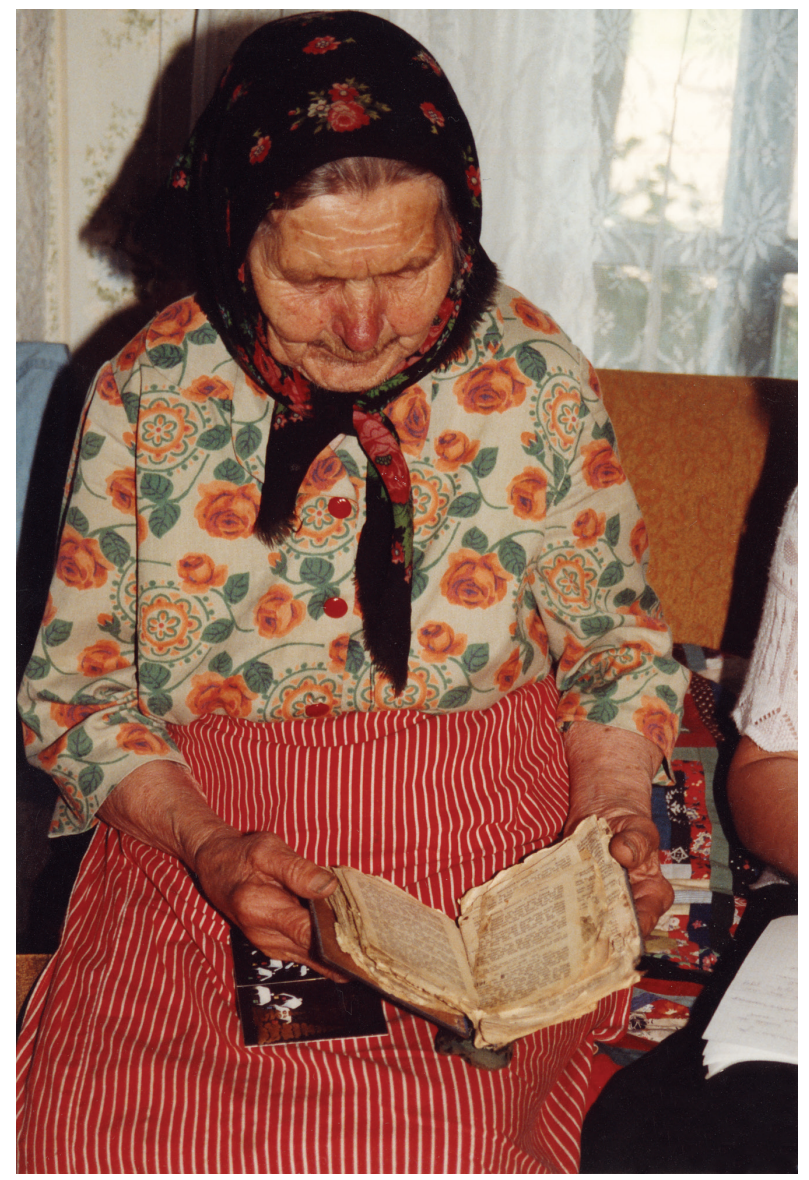


Meil siin praegugi veel mõistva sõnasid: Vertmani Vilma ja Tedre Minna ja... Roosisõnu ja hambasõnu ja valusõnu... Tedre Minna tege musta villa peale roosisõna, a Vilma tege sinitse paberi peale. (EFA I 17, 99 (11) < Omski obl, Mihhailovka k < Morozkino k - naine, snd 1927 (1996))

Rahvauskumuse kohaselt arvati enamik haigusi tulenevat veest, maast, tuulest, surnutelt, nõidusest või pahast silmast. Haiguse päritolu määramine võis saada arstimise tähenduse (Manninen 1925: 453; Loorits 1990: 61-66).

Siberi külade ravitsejad olid oma oskustelt mõistagi erinevad. Mõned oskasid aidata väga paljude hädade puhul: ravisid roosi $^{3}$, panid naba paika, suutsid kõhuvalu leevendada, ravisid paistes jalgu, teadsid abi tuulest tulnud häda vastu, kaotasid soolatüükaid jne. Teised olid õppinud vaid mõnd konkreetset häda leevendama. Seega igast kogukonnast võib leida võimekamaid ja vähem võimekaid ravitseja-oskustega inimesi nagu seda võib öelda ka rahvajutustajate, laulikute või traditsioonilise kombestiku tundjate kohta.

Siberi külakogukondades pöörduti vajadusel esmalt enamasti omade hulgast pärit ja usalduse pälvinud ravitseja poole. Teisest kogukonnast/rahvusest ravitseja tuli kõne alla raskema haiguse või keerulisema probleemi korral. Tõigale, et teisest rahvusest ravitsejatele on sageli omistatud tugevamaid ravivõimeid ja suuremaid oskusi, on osutanud mitmed rahvausundi-uurijad (vt nt Loorits 1928: 17jj). Siberi eestlased on otsinud abi naabritelt lätlastelt ja lähedal asuvatest vene küladest.

No siin oli veike küla üks, kutsuti Kudrinsk. Sialt käis, sial oli misle tark ja vana miesterahvas, arusaaja kovasti. Sial käidi, vahest tuodi siia teda. - Mis hädadega tema juures käidi siis?

- No venitamisest käidi ja kui öeldi pahast silmast ja. [---] Kes oskab arstida, see näeb inimest pialt, mis tal on häda. [---] Vaatab ja ta saab kohe aru, mis sul on häda. Nigu arst. (ERA, CD 451 (18) < Omski obl, Rõžkovo k - naine, snd 1922 (1999))

Räägiti, et Siberi külade eestlased hoiduvad võimalusel tänini riikliku meditsiiniasutuse külastamisest, näiteks Ülem-Suetuki külas nenditi:

Suetukist keegi enne bolnitsa ${ }^{4}$ ei tule, kui ing akkab välja minema. (RKM II 447, 437 (59) < Krasnojarski krai, Ülem-Suetuki k - naine, snd 1920 (1991))

Koidula külas teati jutustada rahvaarstist, kes olnud

... nisukene inime: ühtegi rohtu tema ei tarvitand. Öhessakümmend aastat elas vanaks, kunagi tohtri juures ise ei käind. [---] Inimene peab ise ennast arstima ja ei tohi aige olla. (FAM $78(31,33)<$ Kemerovo obl, Koidula k - naised, snd 1913 ja 1925 (1994)) 
On teateid ka selle kohta, et rahvaarstid on mõnikord oma patsiente aidanud nende haiglaravil olles, kuid mõistes, et arstid seda heaks ei kiida, hoidnud oma tegutsemist arstide eest salajas.

Vaata, Perman Kati oskab arstida kollatõbe vastu, ta on elus. Minu tütar, kis nü̈̈d on Kalatšikus mehel, Leonoorel oli kollatõbi. [---] No laps haige, kõik kollane - viisin polnitsasse, ei miskit, oli nädal aega seal ja ikka hullem, hullem. Siis ma läksin selle Permani Katile ja rääkisin. Permani Kati tegi vie, puoleliitrise pudeli, viisin arstimajasse ja ütlesin akušerkale, ${ }^{5}$ et juoda see vesi ära, et vanemarst ei saaks teada. Ja ta juotis ära. Kaks päeva oli, ja kõlistas, et tule lapsele järele. [---] Ja kollatõbi kadus. (ERA, CD-0010 (36) < Omski obl, Kovaljovo k - naine, snd 1905 (1995))

Siberi kõrvalistes külades sünnitati vähemalt 1950. aastateni kodus. Sünnituse juurde kutsuti mõni vanem sugulane või külanaine, kes kasutas abi andmisel oma pärimuslikke teadmisi ja kogemusi.

Siis oli see Ahuse Liisa. See käis lapsi vasta võtmas. See oli nigu täitsa meil arst kohe. Kõikide lapsed ta vasta võttis. Tiadis nii easti kõik selle luo ja asja ära nigu täitsa arst, nigu käivad nied akušerkad. Sie oligi siis meie külaarst täitsa. (RKM, Mgn. II 4375 (6) < Krasnojarski krai, Ülem-Suetuki k - naine, snd 1922 (1992))

Inimesed toovad jutuajamise käigus esile ka vanu sünnitusega seotud kombeid, kuid nende usundilist tagapõhja sageli enam ei teata.

Tüdrukuga ma jäin reedel haigeks, pühapäeval ta alles sündis. Oma ema ja Jaani sugulane ja onunaine olid seal juures. Mul on meeles, käed koos kõik palusime. Mul juuksed võeti lahti, ma ei tea, mispärast nood juuksed pidi lahti võtma. (ERA, DH 186 (35) < Tallinn < Kemerovo obl, Jurjevi k - naine, snd 1924 (2009))

Sestpeale, kui külades tegutsesid juba eriharidusega velsker-ämmaemandad, pidid nemad vastutama, et sünnitus kulgeks edukalt. Kui ema või lapsega midagi juhtus, võis ämmaemand sattuda lausa kohtupinki (vt nt Korb 2010: 91).

Tervisekäitumist mõjutab paratamatult ka riiklik poliitika. Efektiivseks osutub materiaalsete hoobade kasutamine. Sestpeale, kui Vene Föderatsioonis kehtestati nõue, et lastetoetust saavad taotleda vaid pered, kus ema võtab end enne 12. rasedusnädalat meditsiiniasutuses arvele, on tulevased emad velsker-ämmaemanda hoole all ja sünnitama minnakse haiglasse. Nii on kadunud vajadus küla ämmaemandajate järele ja unustuse hõlma vajuvad ka paljud sünnitusega seotud kombed. 
Tegelikult pole tervishoiukorralduse paranemine ja meditsiiniabi kättesaadavamaks muutumine ka hästiarenenud riikliku meditsiinisüsteemiga riikides kaotanud huvi alternatiivmeditsiini vastu (Alver \& Selberg 1989: 207). Tänapäevalgi on laialt levinud uskumus, et teatud hädade korral (nt roos, tuulest, veest, maast või pahast silmast saadud haigus) ei saa riiklikule arstiabile loota. Seda arvamust kinnitab ka Siberi eestlastelt kogutu, nt:

Poisil olivad nagu krambid. Arst ei saand jagu. Arstid ise soovitasid [pöörduda rahvaarsti poole]. Kümme päeva ma käisin järjest. See Kuznetsova ${ }^{6}$ lausus pudeli sisse. Seda vett pidi söötma-jootma lapsele ja kus on aige, mä̈̈rima ka. Ja tema valas vaha kopsikus, viekopsikusse. Vaha sulatas ja vaha vie sisse. Lausus sinna ja vaha ta korjas ära. Tema ies oled, paneb sinna istuma, kus tal tarvis on. Tema oli jumala usku. Ta vist ütleb, et ehmatand, kas on mõni loom või inimene teda ehmatand. Arstid ise soovitavad neid vanainimesi. (RKM II 466, 472/3 (11-12) < Tomski obl, Vambola k - naine, snd 1936 (1993))

Meil oli siin rajoonis kirurg, ta ise suri ära, neerud olid haiged. Tema juba lõpuotsas ütles, tunnistas, et käige neil vanainimestel, et meie ei saa [roosi vastu] muud teha kui loigata. [---] Näe, roosile ei saa nemad midagi teha. Sie käskis kohe, et minge vanainimestele ja arstige sial. (RKM II 447, 396 (21) < Krasnojarski krai, Ülem-Suetuki k - naine, snd 1929 (1991))

\section{Ravioskuste edasiandmine}

Siberi eestlaste pärimusgrupis antakse ravisõnu ja -oskusi edasi samuti kui muudki pärimuslikku teavet, näiteks laulud, jutud, kalendritavand (vt ka Templing 2005: 215).

Kui Siberi vanemate, väljasaadetutest alguse saanud külade elanikelt pärisin, kas igaüks saab arstida, arvati üsna üksmeelselt:

Saab. Vaikku kes. Ku sa, näe, tahad, küsi. Ta sul kirjutab ja sa lued ja void arstida teise inimese. (ERA, CD 459 (8) < Omski obl, Rõžkovo k naine, snd 1913 (1999))

Nad on jumalasonad. Neid võib hot ${ }^{7}$ kellel. [---] Kes tahab oppida, las opib. Mis jumalasonad on pannetud, neid võib keikidel opetada. (ERA, CD 472 (22) < Omski obl, Rõžkovo k - naine, snd 1921 (1999)) 


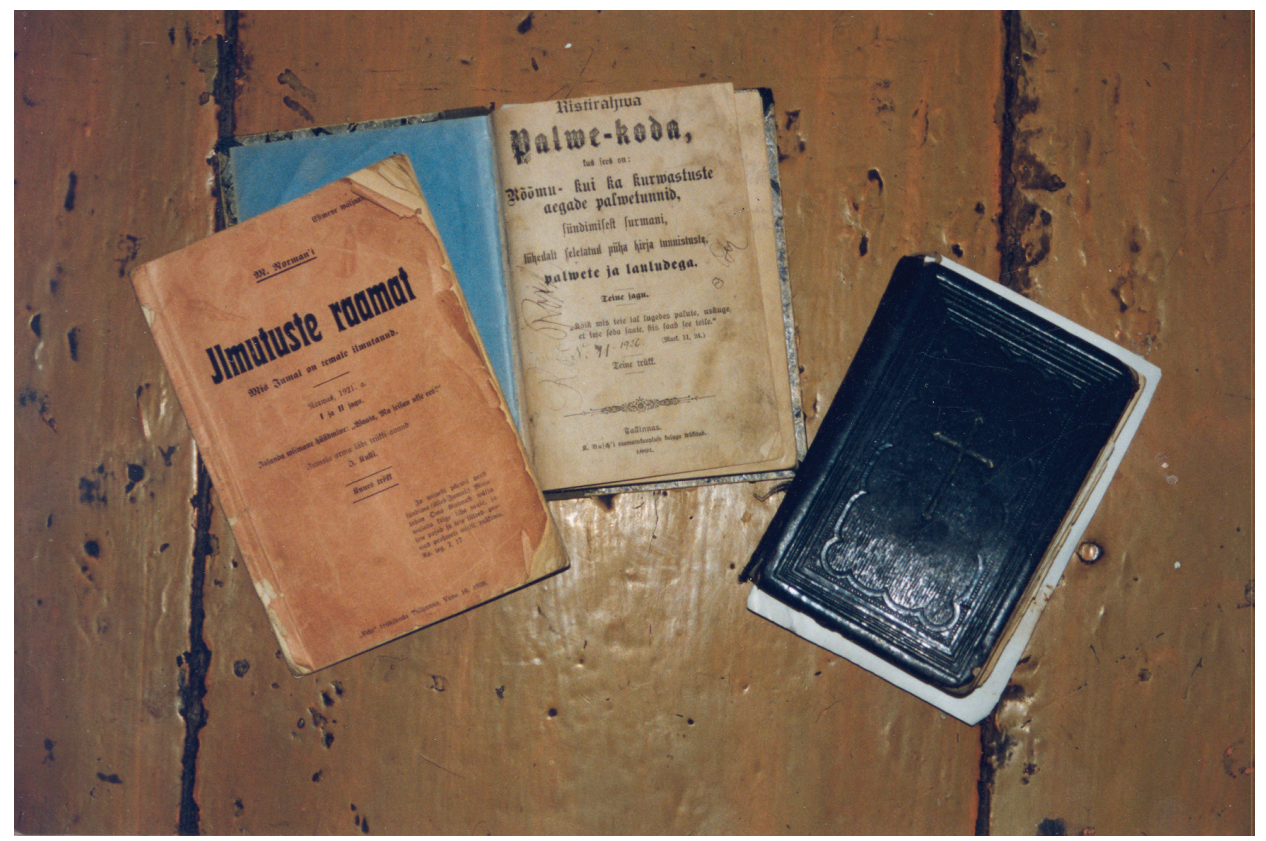

Foto 3. Alma Papakoi jumalasõnaraamatud. Lilliküla. Anu Korbi foto 1996. ERA, VF 339.

Sõnu edasi anda võib küll. Las noored õpivad ja loevad. Mina olen nii paljudele õpetand ja olen lugend, vsjoravno ${ }^{8}$ aitab! See on vale jutt, et ei tohi teisele anda. Ta on ju jumalasõna ja aitab ikka. (RKM II 447, 238 (53) < Krasnojarski krai, Ülem-Suetuki k - naine, snd 1920 (1991))

Loitsutekstide samastamist kõigile soovijatele kättesaadava jumalasõnaga kohtab Siberi eestlaste külades üpris sageli (vt Korb 2006: 93-95). Arstimissõnade samastamist jumalasõnaga mõjutab tavainimeste hulgas nähtavasti asjaolu, et aastasadade vältel on Euroopa kultuuriruumis loitsudena tarvitatud evangeeliumide ümberkirjutusi, palvetekstide osi jms (Kõiva 1998: 200). Loitsutraditsiooni on aegade jooksul lisandunud erineva taustaga kristlikke tekste (Kõiva 1992: 119-123). Meieisa palve on sagedasti arstimissõnade lahutamatu osa (Kõiva 2019: 18).

Issameie-palve on kõige suurem palve. Kopli Leena, minu vanaema, õpetas sammaspoolt 'arstima. Arst ei arsti sammaspoolt ja roosi kah. Tuleb vastapäeva piirata ja seda palvet lugeda. Sääduslikult üteldas kolm korda. Parema käe kolme sõrmega, ja teed risti peale. Jumala käest 
tuleb abi paluda. (RKM II 466, 3 (5) < Kemerovo obl, Jurjevi k - naine, snd 1930 (1994))

Kuna haigus ei taandu tavaliselt üleöö, rõhutavad ka Siberi eestlased, et liiga ruttu ei tasu tulemust oodata:

Iga haiguse vastu on jumalasõna lugemine. Ega ühe korraga millalgi eaks ei saa, peab ikka kolm korda lugema. (RKM II 447, 449 (9) < Krasnojarski krai, Ülem-Suetuki k - naine, snd 1920 (1991))

Ravitseja võib ise oma ravitarkused edasi anda. Nii saanud näiteks üks ÜlemSuetuki küla naine oma ravisõnad venelasest ravitsejalt, kelle juurest ta oma pojale abi otsinud:

Ambavalu vastu meil üks inimene arstib praegu. Areli Anni, ta on kuoli tienija. Mies suri tal ära, elab üksi. Lueb ammastele peale. Anni poeg oli aige, ei saand rääkida. [Anni] käis vene külas arstimas. Nü̈̈d poiss räägib paremini. Ja see vene külast õpetas Annile ka arstimisi. Nüüd Anni arstib meid. (RKM II 447, 397 (46) < Krasnojarski krai, Ülem-Suetuki k - naised, snd 1914, 1916 ja 1921 (1991))

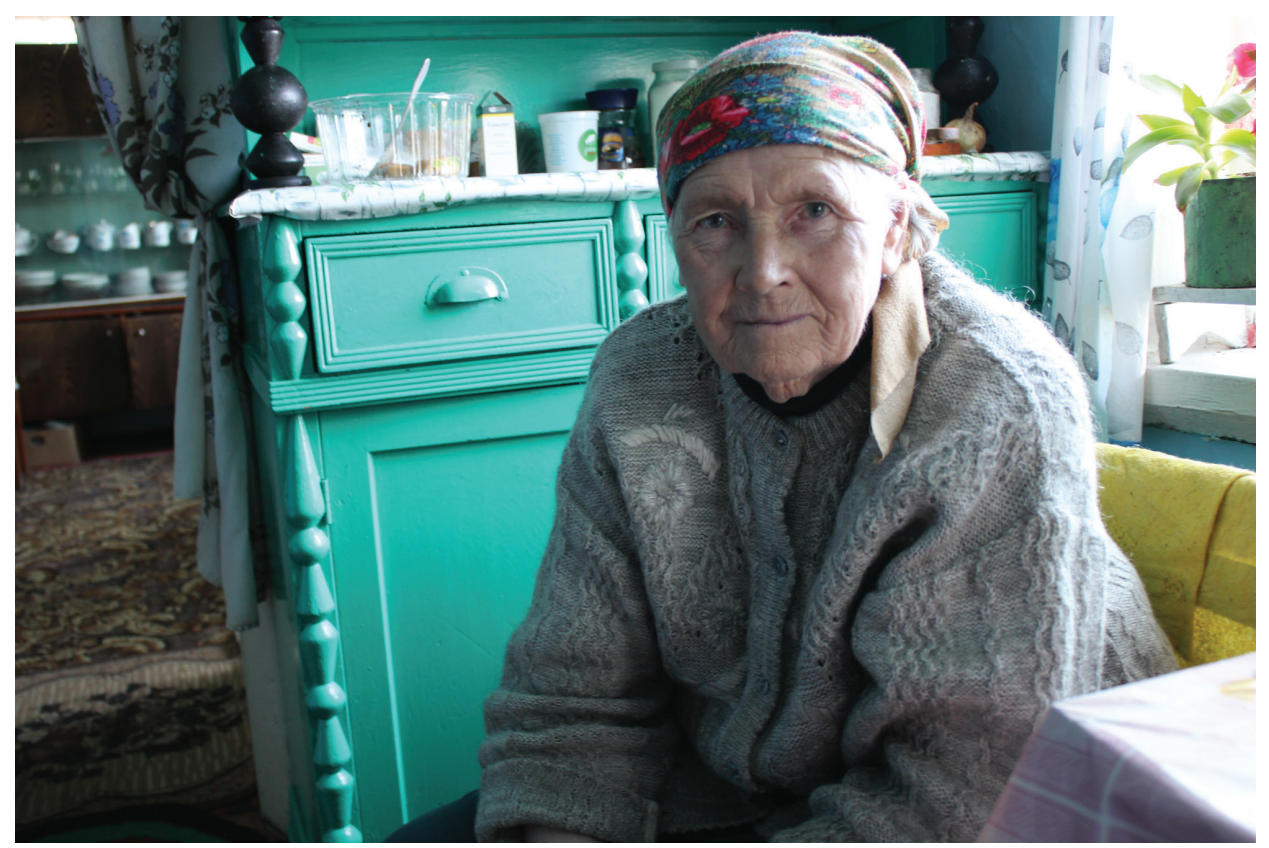

Foto 4. Ravitseja Areli Anni. Ülem-Suetuki k. Anu Korbi foto 2013. ERA, VF 5387. 
Mõned inimesed on ravisõnad saanud ka üsna juhuslikult, näiteks kirjutanud maha kellegi järelejäänud paberitest:

Ma iks ka veidikese arsti. Roosi sõnnu ja eitümise vastu ja kurja silma iist ja... Tsvetnopoljest om need päri. Minu mamma Olga Talvik saie na sõna, Tsvetnopoljest saie, kiruti ära. Vanad poolkustunud paberilehed olid. Ta esi es arsti, vana ol'l, ku saie. Kõige nooremale või kõige vanemale lapsele pead andma sõna üle. Ma ole kõige noorem, ta minule and. (EFA I 17, 25 (3) < Omski obl, Lilliküla k - naine, snd 1937 (1996))

Osa inimesi arvas, et arstimistarkusi võib õpetada vaid endast noorematele:

Endast vanemale ei saa õpetada, ei aita. Siis enam sinu sõnad ei aita. (RKM II 447, 400-401 (54) < Krasnojarski krai, Ülem-Suetuki k - naine, snd 1917 (1991))

Külamees, kes 1992. aasta talvel pärimusekogujale kollatõve ravimist õpetas, jälgis hoolega, et temast vanem naiseõde seda kogemata pealt ei juhtuks kuulma ja sellega tema ravivõimeid ei kahjustaks.

Kuna pärimusekogujad olid teadmiste valdajatest nooremad, ei tekitanud probleeme rahvapäraste ravioskuste edasiandmine Eestist pärit kogujatele. Raviloitsud ja -oskused anti pärimusekogujatele edasi usus, et me neid vajadusel ise praktikas kasutaksime.

Mitmed külaelanikud olid ravisõnu oma tarbeks üles kirjutanud ja lubasid meil need lahkesti kopeerida. Jumalasõnaks peeti ka taevakirju ${ }^{9}$, mille kaitsetoimesse kindlalt usuti. Läti- ja eestikeelsed taevakirjad levisid Baltimaades baltisakslaste vahendusel 18. sajandi lõpul ja 19. sajandi alguses (Põldmäe 1938) ning jõudsid väljarändajatega ka Siberi eesti küladesse (vt Vahtramäe 1998: 180-195). Taevakirjad olid väga paljudes peredes tallel ja seda oli tavaks kanda kaasas teekäigul, tööl vm kodunt eemal (Korb 2019: 75-77).

Teabe salvestamisse ei suhtunud kõik meie vestluskaaslased ühtviisi. Kuna heli- ja videotehnika kasutamine oli 1990. aastatel Siberi külaelanikele veel suhteliselt tundmatu, ei lubanud üksikud külaelanikud, kes jagasid meiega meelsasti oma teadmisi, oma juttu salvestada (vt Korb 2005: 82-86). Samas olid mitmed inimesed nõus ravivõtete ja ravisõnade edastamist demonstreerima ka videokaamera ees, nt saime filmida paha silma vee tegemist, roosisõnade lugemist jm. Kord kehastusin ka mina "patsiendiks". Kui keegi päriselt külas abi vajas, toimetati seda kõrvaliste isikute juuresolekuta, üksnes patsiendi ja ravitseja vahel. 
Lõuna-Eestist väljarännanutest alguse saanud Siberi külades suhtuti oma ravitarkuste edasiandmisesse märksa ettevaatlikumalt kui Põhja-Eesti taustaga külades. Enamasti arvati seal, et kui teadja oma sõnad ja oskused edasi annab, ei saa ta neid enam ise kasutada:

Peredavaitada ${ }^{10}$ sõnnu ka ei saa, siss temä [ravisõnade omanik] enämp ei saa rohitseda. (EFA I 17, 16 (7) < Omski obl, Jurjevi k < mees, snd 1944 (1996))

Üteldass, et teistele ärgu opatagu, et siss endale ei mõiu. Veresõna ma anni Pauliinele, et ku veri nõnast juusk, siss neid sõnnu kirjutatass papre peale ja pandass peale. Ise ma ei saa enamb veresõnu teta. (EFA I 17, 68 (35) < Omski obl, Estonka k < naine, snd 1915 (1996))

Olukord on üsna ootuspärane, sest ka Eestimaa lõunapoolsetes kihelkondades on loitsude edasiandmine rangema keelu all kui põhjapoolsemates piirkondades.

Kogukondades, kus ravitarkusi kõigile vabalt edasi ei antud, arvati, et teadja peab oma järglase ise välja valima. Ja kui sõnad jäävad edasi andmata, on inimesel raske surra:

Sõnu võib anda edasi ütele õnne ${ }^{11}$. Mul üits tütär om õnne ja tuu om tohtri, tuu ei võtakina. Kui keegi sõnu ei võta üle, siss halvaste suret ärä?, ei saa är surede. [---] Piat är? iks andma. Või võõrale [ka] anda. Naisterahvas piab meesterahvale andma, siss om abi, a ku ta naisterahvale [annab], siss nii abi ei saa. Aga kui annad varem need sõnad kellelegi, siss ämp ei tii? sa midägina ${ }^{12}$. (FAM 141 (83) < Omski obl, Semjonovka k - naine, snd 1924 (1995))

Mõni küsitletu arvas, et ravivõimed polegi kõigile ühtviisi kättesaadavad vaid on antud kõrgemalt poolt konkreetsele inimesele:

See on Jumalast antud inimesele, kes saab arstida. Igaüks ei saa. Mina saan arstida, see energia on nagu antud. Ei saa ütelda, et sa oled nõid. Kes mulle ütles, et sa oled nõid... Küll mul oli paha olla! Tule Isa Jumalakene appi! (RKM II 466, 9 (15) < Kemerovo obl, Jurjevi k - naine, snd 1930 (1994))

Avaldati ka arvamust, et oskused tuleb edasi anda teist verd inimesele:

Vanaema teadis palju kunsisid, lapselapsele ei õpetata, teistele õpetatakse. Meukse Juuli oli nimi, a pärast läks Eesti. Tema on Koeravere surnuaias. Tema oli valge ja mina olin valge, nisukesele tuleb õpetada, et teine on teist verd. (RKM II 460, 371 (3) < Tomski obl, Kaseküla k < naine, 64 a (1993)) 
Sageli arvati olevat paremad ravitseja-võimed pere esimesel või viimasel lapsel.

Noh ütlevad, et se'o, et et esimine laps, ja kui see on see nüid, vai viimane laps, et kui on nisukest nagu magneeti vai, et kohe mõjub, et võtab see nüid. Mina olin esimene laps. Ja siss mamma alati mu kässis sie kaala suoni pigistada, kui pia valutas. (ERA, CD-0003 (49) < Omski obl, Tsvetnopolje k - naine, snd 1923 (1997))

Kõige targem peab olema esimene poeglaps. Kui sellele õpetad, siis sellest tuleb kõige parem arst. Kollatõbe ma ravitsen küll, ja kohe saavad ikka terveks. [---] Siin poiss oli, ta enam ei jõ udand kooli minna. Kollatõbi täiesti. Nü̈̈d see Mihkel ütleb ikka mulle, et minu aitaja. [---] Venelane Iljuhhin oli sel'soveti pretsedaat' el. ${ }^{13}$ Jäi kah kollatõbesse. Minu ema [---] ütles: "Mina arstin sind välja." [---] Anna Matt oli mu ema nimi. Tema ei viind sõnu auda. (RKM II 449, 484/8 $(12,13)<$ Krasnojarski krai, ÜlemSuetuki k - mees, snd 1928 (1992))

Ka Lillikülast pärit naine, kes oskas mitmete hädade puhul abi anda, väitis, et sai oma oskused emalt:

Mamma saie ühe vanainimese käest ja mina saien mamma käest. (EFA I 17, 127 < Omski obl, Lilliküla k - naine, snd 1932 (1996))

Seega võivad ravisõnad ja -oskused olla edasi antud vanemalt lapsele. Samas pole vanemad andnud oma teadmisi alati lapsele edasi, mõnikord antakse tarkused edasi üle põlve - lapselapsele.

Sammaspoolt arstin ma esigine ära. Mina olen [pere] esimene laps ja esimene laps võib arstida. Ja mind vanaema õpetas ja mina arstin. Võtad kasetohiku, kolm tohikut võtad. Ja mis suured nõelad om, kellega sukki nõeldass. [---] Tolle nõelaga tiid igale sellele tohikule risti sinna pääle niimoodu ja siss piirad, kus sul sii sammaspool om jälle, vasta päiva kolm ringi, ainult mõtetega, et sa ei loe. Iga tohuga ja siss peab sul tuli põlema kõrraga kohe pliidi all. Võtad selle tohiku ja viskad tulle.

Peab olema seande inimene, kes kõige enne sündinu om. Vanaema oli kõige enne sündinu ja mina olen kõige enne sündinu. Vanaema $a r^{\prime}$ stis ja mina akkasin ka, tema õpetas mind ka ar'stima. (FAM 73 (120) < Kemerovo obl, Jurjevi k - naine, snd 1925 (1994))

Sageli mainiti siiski, et ravioskused tuleb edasi anda vahetult enne surma. Kui teadja oma viimasel tunnil tervisehäda tõttu enam normaalselt rääkida ei saanud, leidis ta lahenduse teksti kirjapaneku näol. 
Roosisõnasi antasse edasi enne surma, lastele. Andressoni Miili, temäl jäi rääkimine ärä ja ta enamb ei saanud. Siss oli minijale paberi pääle kirjutanu tähed - isegi roositähed on oleman. (FAM 87 (3, 6, 8, 10) < Kemerovo obl, Koidula k - naine, snd 1925 (1994))

Kuna üldjuhul oma surmatundi ette ennustada ei osata, on ootamatu surma korral muist esivanemate tarkusest paratamatult jäänudki edasi andmata.

M. L.: Kui läksivad kondid paigast ära - minu taat neid oskas paigale panna. [---] Juba sõrmed või käeluud või.

O. L.: Tema oli Estis mingisugune, päriselt kirikuõpetaja ei old kohe...

M. L.: Vist see köstri...

O. L.: Ja ütles isale ära, et nied sõnad antakse siis edasi, kui haigevoodis viimasel tunnil oled, a enne neid üle ei anta. Aga läks metsa puid lõikama, minu isa räägib, tulime kodu tagasi, oligi juba kodu surnd.

M. L.: Ta villi suri ära.

O. L.: Ei saandki, mitte sõnagi.

M. L.: Oli see hirmus aeg maa peal.

O. L.: Ainult selle õpetas ära, kudas jala kontisi paigale panna. Siin käisivad inimesi meil nii pal'lu, et seda päeva ei oldki, milla neid ei old-üks valu, kõigil paigald ära. Nüid käivad bol'nitsates. (FAM 9 (6) < Tomski obl, Kaseküla k - naine, snd 1923 ja mees, snd 1948 (1993))

\section{Ravioskuste kasutamine ja ravija võimete vähenemine}

Osa inimesi on oma ravioskusi koheselt kasutama hakanud, seega on teateid ka noortest ravitsejatest (vt nt Templing 2005: 214, 226). Levinud tavaarusaam eeldas ravitsejailt siiski suhteliselt soliidset iga. Näiteks Eesti andmed 1929. aastast näitavad, et suuremal osal ravitsejaist oli vanust üle 40 (Rooks 1929: 378). Ühelt poolt oli noorel ravitsejal oma vähese elukogemuse tõttu traditsioonilises külakogukonnas raske end maksma panna, teisalt ei olnud uuele ja moodsale avatud noored alati ise valmis ravitsejana tegutsema (vt Korb 2006: 96).

Mul ol'l ka, mulle üt's vanainemine kir'ut pal'lu sõnnu. Sääl 'hambasõna? olli, ja pallu sõnnu oll, mis võid sa rohitseda. Ja ma ka siss es hooli, nuur olli, edimelt tarre es olõ, kortinan ${ }^{14}$ olli. Kas sinna koheki tõmmassi tuu tetradi ${ }^{15}$, ämp es levvä kätte. (ERA, DAT 26 (13) < Omski obl, Semjonovka k - naine, snd 1922 (1995)) 
Tihtipeale hakati rahvameditsiini oskusi hindama alles siis, kui endal juba lapsed kasvamas:

Minu mamma ajas ikke, et mine, Liisa, kirjuta üles nied arstimised. Ma ütlen, ega ma vanaema ole, et ma lähän kirjutama. A nüid oleks keik kolband. (ERA, CD 451 (10) < Omski obl, Rõžkovo k - naine, snd 1922 (1999))

On loomulik, et vanaduses, mil inimese tervis viletsamaks muutub ja ta ei saa enam kõigega hakkama, vähenevad ka ravija võimed patsienti aidata:

Küsi Jaani käest. Jaan seda nikastuse longa küll teind. Must pesemata lambavillast tehti long ja sella taga tied üheksa sõlme sisse, a see aeg hingata ei tohi. Mina enam tehtud ei saa, ei jõua hinge kinni pidada. Ja siis paned sinna, kus sul on nikastand. Otsi siduda ei tohi, otsad pead kierama. Luomadele tuleb kõige rohkem seda teha. Jaan oli konjuk ja tallimees, obustega tuli ühtelugu seda teha. (RKM II 459, 235/6 (53) < Tomski obl, Liliengofi k < Medodati k - naine, snd 1913 (1993))

Ka halvenenud mälu võis ravitseja edukat tegutsemist takistada, kuid väljapääsuks oli ravisõnade kirjapanek:

Ma ei jõvva änamp [sõnu] pään pidädä. Mul om üles kirutedu. No imä käest kirutasi kõrraga. Kas kõrraga jõvvad pähe oppi tedä! No emä oll ju ar'stenu ja oll ta pääluu sisen. (FAM 141 (84) < Omski obl, Semjonovka k - naine, snd 1924 (1995))

Laialt levinud tõekspidamist, et ravivõimed kaovad ravitsejal hammastest ilma jäädes ja tervise halvenedes (Võrumaa vastava materjali kohta vt Kõivupuu 2000: 55), kinnitab ka Siberi eestlastelt kogutu:

A isi ütlevad, sellel ${ }^{16}$ ei aita, kellel ei ole ammaid enamb suus. (ERA, CD 475 (22) < Omski obl, Rõžkovo k - naine, snd 1927 (1999))

Hoolimata sellest teadmisest on mõned ravitsejad püüdnud ikkagi patsiente aidata. Raviloitse on kasutanud ka mõned kõrges vanuses, viletsa tervisega ja hammastest ilma jäänud inimesed lootuses, et suudavad hädasolija seisundit veidigi kergendada.

Soola on peetud paljudes kultuurides universaalseks abivahendiks. Siberi eestlastelt on teateid soola kasutamisest juhul, kui ravitseja on oma hammastest ilma jäänud.

M.P.: Jaah. A ku ammad ei ole, võtad suolaga, ta juba änam nii ei, ei aita.

A.K.: A mismoodi see soolaga on siis? 
M.P.: No võtad soola suhu ja siss lued seal või. Siis on nigu kõvem...

A.K.: Kas siis pead soola suhu võtma...

M.P.: No lugemise aegas.

A.K.: Kui hambaid enam ei ole, siis võtad soola jah?

M.P.: Mmm, jaa, jaa, jah. Ma ei tia, ma ühte moodi tian aga.

(FAM 145 (54) < Omski obl, Kovaljovo k - naine snd 1915 (1995))

Põhjusena, miks ravitsemisest pole iga kord abi olnud, on siberlaste traditsioonis juurdunud teadmine, et patsiendil tuleb paljude ravitsejate seast leida verd mööda ravitseja. Näiteks korduvalt roosihaigust põdenud naine pöördus alati sama ravitseja juurde tagasi - kelleltki teiselt ei uskunud ta abi saavat.

Igaühel ei aita, igaühega. Vot see sama ruoski. Mõnikene ku lueb, nii hakkab hullemini valutama. Kelle, kes, veri ei ole selle järel vai mis ei lähe et...

- Nii et pead vaatama, kelle lugemine sulle aitab siis?

- No lued, ku ta aitab, sis ta kohe aitab. A kui ei aita, sis, sis enamb ei saa minna, sis hakkab veel rohkem valutama neist kohe, kohe tunned sis. (ERA, CD 468 (5) < Omski obl, Rõžkovo k - naine, snd 1915 (1999))

Sageli mainiti ka, et ravisõnad ei mõju ristimata inimesele.

Mina olen teisi abistand. Tulevad mu juurde abi otsima. Peavad ristitud olema, muidu ei aita. Ta ei ole ristitud, siis segab seda lugemist ja ei ole nigu on tarvis. Noh nü̈̈ hakkavad rohkemjagu ristima juba kõik ära. (EFA II 2, 234/5 (12); ERA, CD-0011 (29) < Omski obl, Kovaljovo k naine, snd 1916 (1995))

Oluline olevat jälgida ka kuu seisu - vana ja noort kuud. Soodsaks on analoogiamaagia põhjal - noor kuu kasvatab, vana kaotab - peetud ravitsemist vana kuu ajal.

Tuientadis Kaseküla omasid palju kohe käis seal. Mina kui käisin, oli kohe järjekord seal. Masinad seisivad. Arstid ise käivad seal ja. Noores kuus ta ei akkagi. Vana kuu otsa sees tema arstib. Ja näiteks: esmaspäev, teisipäev ja kesknädala ta arstib naisterahvaid. Meesterahvas kui läheb: neljapäev, reede ehk laupäev. Esimest korda kui lähed, aga pärast võib juba iga päev minna. Kel selg aige ehk kel magu aige - ta triigib ka. (RKM II 460, 75/7 (25) < Tomski obl, Kaseküla k < naine, snd 1935; mees, snd 1938 (1993)) 


\section{Kokkuvõtteks}

20. sajandi viimase kümnendi välitööd Siberi eestlaste juures tõid Eesti Rahvaluule Arhiivi hulga väärtuslikku pärimusmaterjali. Kuigi riikliku meditsiini võidukäik oma väikehaiglate ja velskripunktidega oli jõudnud Siberi küladesse ligi pool sajandit varem ning aastakümnete jooksul oli rahvaarstide tegutsemine keelustatud, üllatas kogujaid ravitsejate rohkus külades ja rahvameditsiini ulatuslik kasutamine. Uusi teadmisi omandati ka vene vm rahvusest ravitsejailt, ravisõnu on maha kirjutatud juhuslikult leitud paberitest jm. Vanemates, väljasaadetutest alguse saanud Siberi eestlaste kogukondades (nt Ülem-Suetuk, Rõžkovo) levis arvamus, et ravisõnad ja -oskused on igaühele kättesaadavad ja õpitavad, neid samastati sageli jumalasõnaga. Osa inimesi arvas, et ravioskusi võib kõigile soovijaile edasi anda, teised teadsid, et teadmisi-oskusi võib jagada vaid endast noorematega. Väljarännanutest alguse saanud külades suhtuti ravisõnade jm oskuste edasiandmisse märksa ettevaatlikumalt. Enamikus Lõuna-Eesti taustaga külades hoiti oma teadaolevad raviloitsud kiivalt omateada. Neis külades usuti, et teadmiste jagamise korral kaotab ravitseja oma võimed. Nii püüdsid paljud targad järglase välja õpetada alles oma surivoodil, kuid äkilise surma korral võisid tarkused jääda ka edastamata. See, kellele oskused edasi anti, ei pidanud tingimata kuuluma lähisugulaste ringi. Rohkem eeldusi edukaks ravitsejaks saada arvati olevat pere esimesel või viimasel lapsel. Kõik inimesed, kellele on tahetud ravioskusi üle anda, pole olnud valmis ravitseja vastutusrikast ametit kandma. Rahvameditsiooni traditsiooni (nagu ka muu pärimuse) kandjate seas oli meestest märksa enam vanemaid naisi, mis oli tingitud ühelt poolt demograafilisest olukorrast, teisalt naiste juhtpositsioonist kogukonna traditsioonide suunamisel ja hoidmisel.

21. sajandi esikümnendil oli olukord ka vanemates Siberi külades ravisõnade ja -oskuste edasiandmisel suuresti muutunud. Paljud teadjad olid jõudnud teispoolsusse, noori, kes oleksid traditsiooni jätkamisest huvitatud, polnud piisavalt. Nii olid ravitsemisoskused paratamatult koondunud üksikute tarkade kätte. Nad tunnetasid oma eristaatust ega jaganud teadmisi enam vabalt kõigile soovijaile nagu oli varem neis külades kombeks. Siberi eesti kogukondade rahvaravitraditsioon on hääbumas eeskätt kogukondade kiire vähenemise ja vananemise tõttu. 


\section{Tänusõnad}

Artikli valmimist on toetanud Eesti Kirjandusmuuseumi uurimisgrant EKM 8-2/20/2 (Folkloor ja selle individuaalsed, kogukondlikud ja institutsionaalsed edasiandmise mehhanismid), Haridus- ja Teadusministeeriumi projekt EKKD65 (Kuidas allikatest saab kultuur: eesti aines Eesti Kirjandusmuuseumi kogudes ja andmebaasides) ja Eesti-uuringute Tippkeskus (TK 145) Euroopa Regionaalarengu Fondi kaudu.

\section{Kommentaarid}

1 1991. aasta Siberi välitöödel osalesid Anu Korb ja Astrid Tuisk. Kogutu on arhiivis RKM II 447, 216-537; RKM, Mgn. II 4363-4367.

${ }^{2}$ Isegi (vn).

3 Roos (vanem nimetus eliting, ka pahus) tähistas põletikulisi suurte valudega haigusi roosist luutuberkuloosi ja keskkõrvapõletikuni. See arvati tekkivat ehmatusest või mõnest afektsest seisundist. Arvati olevat üheksa liiki roosi (Kõiva 2011: 233).

4 Haiglasse (vn).

5 Ämmaemandale, siin: meditsiiniõele (vn).

6 Venelannast arstija.

7 Ükskõik (vn).

8 Nagunii, ikka (vn).

9 Taevakiri (ka Taevaraamat, Neitsi Maarja unenägu vms) on pärimuse kohaselt taevast saadetud või alla visatud üleloomulike omadustega kaitsekiri, mis sisaldab ka tsitaate piiblist.

${ }^{10}$ Edasi anda (vn).

${ }^{11}$ Ainult.

${ }^{12}$ St ei saa enam ise ravida, ei mõju.

${ }^{13}$ Külanõukogu esimees (vn).

${ }^{\mathbf{1 4}}$ Korteris.

${ }^{15}$ Vihiku (vn).

${ }^{16}$ St selle ravimine.

\section{Arhiivimaterjalid Eesti Kirjandusmuuseumis}

EFA - Eesti Rahvaluule Arhiivi käsikirjaline kogu alates 1995. aastast.

ERA, CD - Eesti Rahvaluule Arhiivi digitaalsalvestused CD-del.

ERA, DAT - Eesti Rahvaluule Arhiivi DAT magnetofoni salvestused. 
ERA, DH - Eesti Rahvaluule Arhiivi digitaalsalvestused arvuti kõvakettal.

FAM - analoogsalvestused stereokassettidel.

RKM - Riikliku Kirjandusmuuseumi (nüüd Eesti Kirjandusmuuseumi) käsikirjaline rahvaluulekogu kuni aastani 1994.

\section{Kirjandus}

Alver, Bente G. \& Selberg, Torunn 1989. Alternative Medicine in Today's Society. Kvideland, Reimund \& Sehmsdorf, Henning K. (toim). Nordic Folklore. Recent Studies. Indiana University Press, lk 207-220.

Ashwin, Sarah 2000. Introduction: Gender, State and Society in Soviet and Post-Soviet Russia. Ashwin, Sarah (toim). Gender, State and Society in Soviet and Post-Soviet Russia. London and New York: Routlege, lk 1-29.

Granö, Paavo 1999 [1915]. Siperian suomalaiset. Kajanto, Anneli (toim). Namsarai ja muita matkaesseitä Kansanvalistusseuran kalentereista autonomian ajalta. Helsinki: Suomalaisen Kirjallisuuden Seura, lk 122-133.

Korb, Anu 2005. Venemaal rahvuskaaslasi küsitlemas. Folkloristliku välitöö metoodilisi aspekte. Studia Ethnologica et Folkloristica Tartuensia 9. Tartu: Tartu Ülikooli Kirjastus.

Korb, Anu 2006. Ravitsemisoskus kui pärimusrühma ühisteadmus: Siberi Rõžkovo küla näide. Mäetagused 34, lk 87-110 (doi: 10.7592/MT2006.34.korb).

Korb, Anu (koost, toim) 2010. Siberi eestlaste elud ja lood. Eesti asundused V. Tartu: Eesti Kirjandusmuuseumi Teaduskirjastus.

Korb, Anu 2017. Kohtumised Siberis. Eesti asundused VIII. Tartu: Eesti Kirjandusmuuseumi Teaduskirjastus.

Korb, Anu 2019. Ida-Siberi Minussinski piirkonna eestlaste ravitsejad, haigusseletused ja ravivõtted. Traditsioonimuutused ja kogumiskontekst. Kalmre, Eda (toim). Pildi sisse minek. Artikleid välitööde alalt. Tänapäeva folkloorist 11. Tartu: EKM Teaduskirjastus, lk 59-86 (doi: 10.7592/TF11.korb).

Kulu, Hill 1997. Eestlaste tagasiränne 1940-1989. Lääne-Siberist pärit eestlaste näitel. Tartu: Tartu Ülikooli Kirjastus.

Kõiva, Mare 1992. Loitsud ja rahvaarstid. Rüütel, Ingrid (toim). Ida-Virumaa rahvakultuurist. Tallinn: AS Infotrükk, lk 117-131.

Kõiva, Mare 1995. Loitsust riituseni. Hiiemäe, Mall \& Kõiva, Mare (toim). Rahvausund tänapäeval. Tartu: Eesti Keele Instituut, lk 175-194 (http://www.folklore.ee/rl/pubte/ ee/usund/eesti/koiva.pdf - 10. november 2020).

Kõiva, Mare 1998. Palindroomidest, aga ennekõike tähtvormelitest. Kalda, Mare \& Kõiva, Mare (toim). Sator I. Artikleid usundi- ja kombeloost. Tartu: Eesti Keele Instituut, rahvausundi töörühm, lk 190-213 (http://www.folklore.ee/rl/pubte/ee/sator/ sator1/sator1-11.pdf - 10. november 2020). 
Kõiva, Mare 2011. Eesti loitsud. Tallinn: Pegasus.

Kõiva, Mare 2019. Eesti loitsud. Arstimissõnad I. Monumenta Estoniae Antiquae VI. Tartu: Eesti Kirjandusmuuseumi Teaduskirjastus.

Kõivupuu, Marju 2000. Rahvaarstid Võrumaalt. Noor ja vana Suri Hargla kihelkonnast. Võru: Võro Instituut.

Kõivupuu, Marju 2013. Igal hädal oma arst, igal tõvel ise tohter. Sissevaade eesti rahvameditsiini. Varrak.

Loorits, Oskar 1928. Liivi rahva usund III. Mit einem Referat: Der Volksglaube der Liven. Acta et Commentationes Universitatis Tartuensis (Dorpatensis) = Tartu Ülikooli toimetused B (Humaniora) 16: 1. Tartu: [Tartu Ülikool].

Loorits, Oskar 1990. Eesti rahvausundi maailmavaade. Tallinn: Perioodika.

Manninen, Ilmari 1925. Üldjooni meie rahvameditsiinist. Eesti Kirjandus 11, lk 453-459.

Must, Aadu 2012. Siber ja Eesti. Jalaraua kõlin. Tartu: Tartu Ülikooli Kirjastus.

Nigol, August 1918. Eesti asundused ja asupaigad Venemaal. Tartu.

Põldmäe, Rudolf 1938. Die früheste Verbreitung der Himmels-briefe in Estland. Acta ethnologica. Kobenhavn, lk 100-115.

Rooks, G. 1929. Ebaarstimine Eestis. Eesti Arst 10, lk 377-382.

Templing = Templing, Vladimir Iakovlevich 2005. Sel'skie vrachevateli v sibirskom sotsiume. Karabulatova, Irina S. (toim). Zhivaia traditsiia zagovora Sibiri: sakral'noritual'nyi diskurs znakharskoi praktiki. Tiumen': Aleteiia, lk 213-299.

Vahtramäe, Ell 1998. Taevakirjad Siberi eesti asundustes. Tuisk, Astrid \& [Hiiemäe, Mall \& Tamm, Kadri] (toim). Eesti kultuur võõrsil. Loode-Venemaa ja Siberi asundused. Konverentsi ettekanded. Tartu: Eesti Kirjandusmuuseum, lk 180-194.

Viikberg, Jüri \& Vaba, Lembit 1984. Siberi põhjaeestlasi kõnetamas I. Keel ja Kirjandus 3 , lk 145-156.

\section{Summary}

\section{Healers in Siberian Estonian communities}

\section{Anu Korb}

Senior Research Fellow

Estonian Folklore Archives, Estonian Literary Museum anu.korb@folklore.ee

Keywords: community, folk medicine, healers, Siberian Estonians

The article is based on manuscripts as well as sound and video recordings on folk medicine collected during fieldwork conducted by the researchers of the Estonian Folklore Archives in 1991-2013 from Estonians born and raised in different Siberian Estonian 
communities. The ancestors of the visited Estonians had either left their homeland in search of land in the last decades of the 19th and the beginning of the 20th centuries or were descendants of those deported and exiled by the Russian tsarist authorities in the first half of the 19th century.

Fieldwork at Siberian Estonians in the last decade of the 20th century enriched the Estonian Folklore Archives with invaluable lore material, including the material related to folk medicine. Although the advance of the state medicine system with small hospitals and first aid posts had reached Siberian villages half a century before, and the activity of healers had been banned for decades, the collectors were surprised by the number of healers in villages and the extent of the practical use of folk medicine. The folk medicine tradition was upheld mostly by older women (as was the case also with other fields of lore), which resulted, on the one hand, from the demographic situation, and, on the other hand, from women's leading position in the preservation of communal traditions.

In the older Siberian Estonian communities, which had been established by the deportees (e.g. Ülem(Upper)-Suetuk, Ryzhkovo), it was believed that healing words and skills were available and could be learned by anyone; they were often compared to God's word. Some people thought that knowledge and skills could only be shared with those younger than yourself. In the villages established by exiles people were considerably more cautious about passing on healing words and the like. In most villages with southern Estonian background, healing charms were kept in secret, as it was believed that when sharing their knowledge, the healers would lose their abilities. It was only at their death's door that the healers selected their successor. Not all the people who were offered to learn the healing skills were ready to accept the responsibility. The first or last child in the family was thought to have more prerequisites for becoming a good healer.

In the first decade of the 21 st century, the situation with passing on the healing words and skills had changed considerably in older Siberian villages. Many of the healers had passed away, and there were not enough young people who were interested in continuing the tradition. So the healing skills inevitably concentrated into the hands of a few wise women. Currently, the folk healing tradition in Siberian Estonian communities is fading away, above all, due to the fast aging and diminishing of the communities.

Anu Korb on Eesti Kirjandusmuuseumi Eesti Rahvaluule Arhiivi vanemteadur. Tema kogumis- ja uurimisvaldkonnaks on olnud Siberi eesti kogukonnad. Ta on korduvalt teinud välitöid erinevates Siberi eesti kogukondades, kogutu põhjal koostanud kommenteeritud teksti- ja lauluantoloogiaid. Oma teadustöödes on ta käsitlenud Siberi eestlaste laulutraditsiooni, rahvameditsiini, eluloolisi mälestusi, Siberist kogutu põhjal folkloristliku välitöö eri aspekte.

Anu Korb is Senior Research Fellow at the Estonian Folklore Archives of the Estonian Literary Museum. Her main collection and research field is Siberian Estonian communities. She has carried out fieldwork in different Siberian Estonian communities and compiled commented text and song anthologies. 
Anu Korb

Her research is dedicated to Siberian Estonians' song tradition, folk medicine, life stories, and different aspects of folkloric fieldwork based on the material collected in Siberia.

anu.korb@folklore.ee 